\author{
기후변화에 따른 도시별 기상기여도 차이가 \\ 고농도 오존분포에 미치는 영향 \\ 정여민 · 이화운 ${ }^{*}$ 최현정 ${ }^{1)}$ \\ 부산대학교 지구환경시스템학부, ${ }^{1)}$ 부산대학교 환경연구원 \\ (2011년 2월 17일 접수; 2011년 3월 4일 수정; 2011년 3월 10일 채택)
}

\title{
The Impact of Regional Warming On the Ozone Concentration According to the Differences in Meteorological Contribution in Each City over the South-Eastern Part of the Korean Peninsula
}

\author{
Yeo-Min Jeong, Hwa Woon Lee*, Hyun-Jung Choi ${ }^{1)}$ \\ Division of Earth Environmental System, Pusan National University, Busan 609-735, Korea \\ ${ }^{1)}$ Institute of Environmental Studies, Pusan National University, Busan 609-735, Korea \\ (Manuscript received 17 February, 2011; revised 4 March, 2011; accepted 10 March, 2011)
}

\begin{abstract}
In order to clarify the impact of regional warming on the ozone concentration according to the differences in meteorological contribution in each city over the South-Eastern part of the Korean Peninsula, several numerical experiments were carried out. WRF - CMAQ model was used to access the ozone differences in each case, during the episode day. Meteorological contributions estimated by WRF command a reasonable feature on the dispersion of ozone concentrations in each city according to regional warming. This causes a difference in estimated ozone concentration. A higher ozone concentration difference tend to be forecasted in coastal cities than in upcountry city. Therefore, the emission reduction policy according to the regional warming should consider the characteristics of meteorological contribution of each city.
\end{abstract}

Key Words : Regional warming, Meteorological contribution, Ozone concentration, WRF - CMAQ

\section{1. 서 론}

지구규모의 기온상승은 전 지구적인 기류 뿐 아니 라 국지규모의 기류 변화에도 영향을 미칠 것으로 예 상된다. 또한 기온 상승은 단순히 기상장의 변화 뿐 아 니라 대기오염 특히 광화학 반응성 오염 물질의 농도 변화에도 영향을 미친다 (Jianhui 등, 2005; Gabriel와

\footnotetext{
${ }^{*}$ Corresponding author : Hwa Woon Lee, Division of Earth Environmental System, Pusan National University, Busan 609-735, Korea

Phone: +82-51-583-2651

E-mail: hwlee@pusan.ac.kr
}

Brian, 2007; Fujibe, 2009; Carvalho 등, 2010). Camalier 등(2007)은 미국 39개 대도시의 오존농도의 시간 변화를 분석한 결과 오존농도가 지표면 기온과 습도의 변화와 밀접하게 관련된다고 보고하였으며, John 등(2007)은 미국 동부 지역의 기후 변화에 따른 기상장 변화를 수치모의 하고 민감도 분석을 통해 기 후 변화에 따른 오존 농도의 분포를 연구하였다. 특히 한반도를 포함한 동아시아지역의 기온 상승이 급격하 게 이루어지고 있기 때문에 이 지역의 기온 상승이 국 지규모의 기상에 미치는 영향을 정확히 파악할 필요가 있다. 따라서 지구온난화에 따른 기후변화가 국지규모 의 기류변화와 광화학 반응성 오염물질의 농도변화에 
직간접적으로 영향을 미침을 가정하고 그 영향에 관한 세밀한 연구와 정책적인 접근이 필요하다고 판단되었 다. 따라서 장기적인 환경 변화 예측의 측면에서 지구 온난화에 따른 이들 도시에서의 국지기상장의 변화와 이에 따른 대기오염의 변화 경향성을 파악하고자 한다.

본 연구에서는 복잡한 국지순환계가 나타나는 한 반도 동남지역 대도시를 대상으로 대표적인 2 차 대기 오염 물질인 오존의 기상요인에 의한 변동성을 살펴 보고, 기상장과 대기질 수치모의를 통하여 지구 온난 화를 가정한 기상 변화로 인한 도시별 오존 농도의 변 동성을 살펴보고자 하였다.

\section{2. 자료 및 방법}

\section{1. 수치모의 설계}

\subsection{1. 기상장 수치모의}

본 연구에서는 동남지역 대도시(부산, 울산, 대구) 의 고농도 오존 사례일 중 종관장의 영향이 크지 않고 맑았던 2008년 5월 2일 0900LST부터 4일 0900LST까 지를 사례일로 선정하였다. 기상장 수치 모델의 초기 입력장은 미국 해양대기관리청의 국립환경예측센터 에서 제공하는 1.0x1.0 FNL (Final Operational Global Analysis data)을 사용하였고, 경계조건에서의 수치모 델링 계산 오차를 줄이기 위해 3 개의 둥지격자를 설정 하여 nesting 방법을 이용하였다. 동남지역을 중심으 로 설정한 마지막 도메인 영역은 $1 \mathrm{~km}$ 해상도의 가로 와 세로의 격자수를 199 개로 하여 수치모의 하였고
모델링 영역은 Fig. 1 에 나타내었다. 지형 및 토지이용 자료는 미국항공우주국에서 제공하는 3 초 지형자료 인 SRTM (Shuttle Radar Topography Pission) 3 초와 환경부에서 제공하는 1 초 토지이용 자료인 $\mathrm{KLU}$ (Korea Land Use) 1초를 사용하였다. SRTM 3초 자 료는 1 도의 영역이 1,200 개 격자로 표현되므로 USGS (United States Geological Survey) 30초 자료에 비해 해상도가 10 배 높으며, KLU 1초 자료는 환경부에서 Landsat M 위성영상과 SPOT 위성 영상의 합성을 통 해 제작한 토지 이용 자료로서 USGS 토지 이용 자료 에 비해 해상도가 30 배 높아 수치모의에서의 정확도를 향상시켰다(Lee 등, 2008; 전원배 등, 2009). 수치모의 에 사용된 물리 모수화 방안은 Table 1에 나타내었다.

Table 1. The configuration of WRF modeling

\begin{tabular}{cccc}
\hline & Domain 1 & Domain 2 & Domain 3 \\
\hline \hline Horizontal grid & $190 \times 190$ & $214 \times 214$ & $199 \times 199$ \\
\hline $\begin{array}{c}\text { Horizontal } \\
\text { resolution }\end{array}$ & $9 \mathrm{~km}$ & $3 \mathrm{~km}$ & $1 \mathrm{~km}$ \\
\hline \multirow{2}{*}{ Vertical layers } & \multicolumn{2}{c}{28 layers } \\
\hline \multirow{2}{*}{$\begin{array}{c}\text { Physical } \\
\text { options }\end{array}$} & Kain-Frisch(new Eta) cumulus scheme \\
\cline { 2 - 3 } & \multicolumn{2}{c}{ YSU scheme } \\
\cline { 2 - 3 } & \multicolumn{2}{c}{ RRTM long-wave scheme } \\
\hline Initial data & $\begin{array}{c}\text { NCEP FNL Opherational Global } \\
\text { Analysis data }\end{array}$ \\
\hline Time Period & $\begin{array}{c}\text { 2008. 05. 02. 0900LST } \\
\text { 2008. 05. 04. 0900LST }\end{array}$ \\
\hline
\end{tabular}

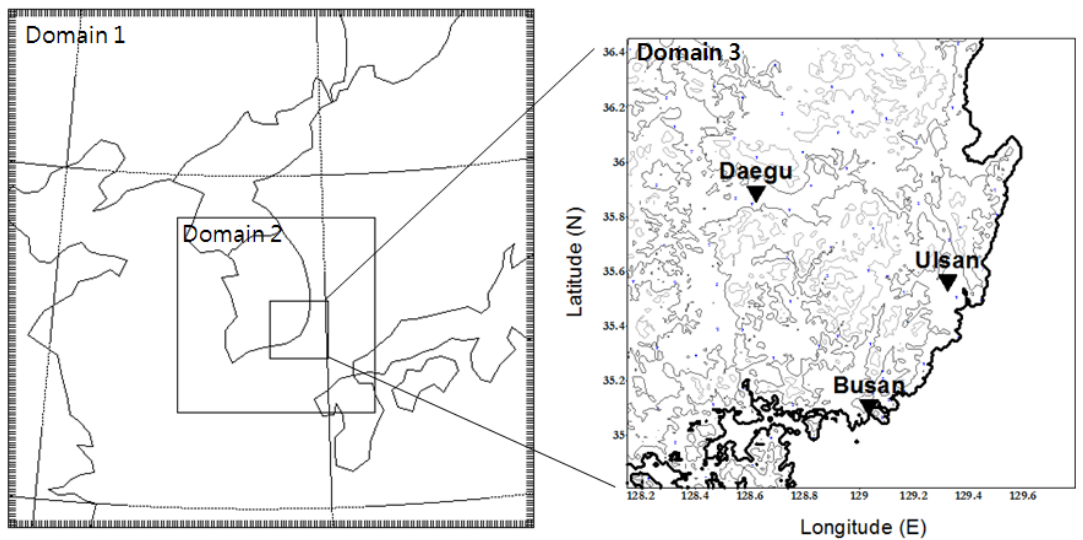

Fig. 1. WRF model domains and nested domain used in this study. 


\subsection{2. 대기질 수치모의}

$\mathrm{WRF}$ 모델 결과를 대기질 수치모의 입력자료로 사 용하여 대기질 수치모의를 수행하였다. 동남지역의 대표 도시가 포함되는 WRF 수치모의 Domain 3에서 경계값의 오차가 나타나지 않을 범위를 지정하여 186 $\times 186$ 수평격자로 설정하였다. $\mathrm{CMAQ}$ 의 구성은 Table 2에 나타냈다.

Table 2. The configuration of CMAQ modeling

\begin{tabular}{cc}
\hline & CMAQ domaion \\
\hline \hline $\begin{array}{c}\text { Input } \\
\text { Data }\end{array}$ & WRF Domain 3 Output Data \\
\hline $\begin{array}{c}\text { Horizontal } \\
\text { Grid }\end{array}$ & $186 \times 186$ \\
\hline $\begin{array}{c}\text { Horizontal } \\
\text { Resolution } \\
\text { Vertical } \\
\text { Layers }\end{array}$ & $1 \mathrm{~km}$ \\
\hline $\begin{array}{c}\text { Emission } \\
\text { Data }\end{array}$ & 28 layers \\
\hline $\begin{array}{c}\text { Chemical } \\
\text { Mechanism }\end{array}$ & CAPSS \\
\hline $\begin{array}{c}\text { Time period } \\
\text { CB-IV }\end{array}$ \\
\hline
\end{tabular}

CMAQ 모델링 수행시 사용된 배출량 자료는 CAPSS (Clean Air Policy Support System)를 이용하여 산정 하였다. CAPSS는 국립환경 연구원에서 생산하는 배출 물질을 격자별 연간 총 배출량의 형태로 제공한다. 광화 학 수치모의 수행시 사용된 반응 메커니즘은 CB-IV (Carbon Bond Mechanism - Version IV)로 36개의 물 질을 고려하고 93 개의 화학반응을 고려한다. 대기질 수치모의 기간은 기상장 수치모의와 동일하게 48 시간 으로 설정하여 수치 계산을 실시하였다. 기온과 풍속 의 변화에 따른 오존 농도의 지역별 분포를 살펴보기 위해 $\mathrm{CMAQ}$ 에서 각 기상요소를 변화시킨 실험을 실 시하였다. Fig. 2에 나타낸 MCIP은 기상장 수치모의
의 결과를 광화학 모델링을 수행할 기상장으로 변환 시키는 과정으로, 본 연구에서는 MCIP에서 기온을 변화시킨 case T와 풍속을 변화시킨 case WS의 실험 을 설정하였다(Table 3). IPCC 4차 보고서의 기후변화 시나리오에 따라 향후 100 년간의 기온상승이 $2.4^{\circ} \mathrm{C}$ $6.4{ }^{\circ} \mathrm{C}$ 로 예상되므로 case $\mathrm{T}$ 의 실험은 $2^{\circ} \mathrm{C}$ 와 $6^{\circ} \mathrm{C}$ 를 상 승시킨 case $\mathrm{T} 2$ 와 case $\mathrm{T} 6$ 로 실시하였다. 기후변화에 따른 풍속의 변화는 명확한 예측이 어려운 실정으로 국지적 기상과 지형의 차이가 풍속의 변화를 유도할 것이라는 잠정적인 연구결과가 있다. John 등(2007) 이 기후 변화에 따른 기상요소의 변화로 미국 동부지 역의 오존 분포를 모델링을 실시한 연구에서 풍속의 변화에 따른 오존의 농도를 수치모의 한 선행연구에 따라 case WS의 실험은 풍속을 $10 \%$ 상승시킨 case $\mathrm{WS} 10 \%$ 와 $20 \%$ 상승시킨 case $\mathrm{WS} 20 \%$ 의 기상장으 로 수치실험을 실시하였다.

Table 3. Design of the Air Quality Modeling

\begin{tabular}{cccc}
\hline & case & case T2 & Increase temperature $2{ }^{\circ} \mathrm{C}$ \\
\cline { 2 - 3 } Experiments & $\mathrm{T}$ & case T6 & Increase temperature $6{ }^{\circ} \mathrm{C}$ \\
\cline { 2 - 3 } & case & case WS10\% & Increase wind speed $10 \%$ \\
\cline { 2 - 3 } & WS & case WS20\% & Increase wind speed $20 \%$ \\
\hline
\end{tabular}

\section{3. 대기질 수치모의 결과}

\section{1. 기온 변화에 따른 오존 농도}

Fig. 3 에는 두 수치모의 결과와 기상장 변화를 주지 않고 사례일의 기상장 수치모의 결과를 적용시킨 사 례(case BASE)의 수평장의 차이를 나타내었다. case $\mathrm{T} 2$ 와 case T6의 $0900 \mathrm{LST}$ 의 경우 오존의 형성이 시 작되는 울산 지역에서 각각 양의 값이 나타나 기온의 상승이 오존 형성 초기의 농도를 증가시키는 것을 확

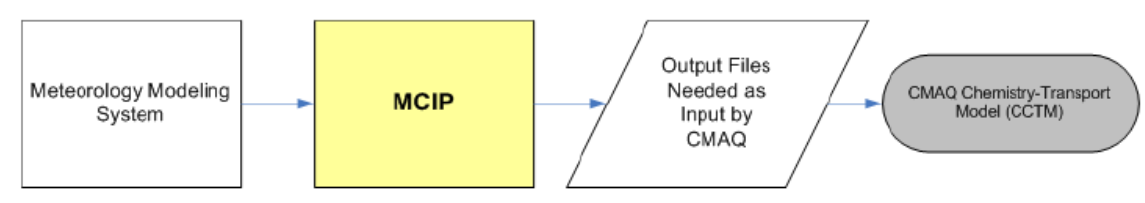

Fig. 2. Meteorology preprocessing for CMAQ with MCIP. 
인 할 수 있었다. case $\mathrm{T} 2$ 의 경우 울산 지역을 제외하 고는 차이가 나타나지 않았으나 case $\mathrm{T} 6$ 의 경우 내륙 의 낮은 고도가 나타나는 지역으로 양의 값이 나타나 서 내륙에서의 오존형성이 기온 상승으로 인해 빠르 게 나타나는 것을 알 수 있었다. $1500 \mathrm{LST}$ 의 경우 값 의 차이가 크게 나타났는데 먼저 case T2의 경우에는 울산에서 형성되어 부산 지역으로 이류된 오존의 농 도가 case BASE에 비해 $10 \mathrm{ppb}$ 정도 높게 나타났으 며 대구와 진해로도 오존이 최고 $3 \mathrm{ppb}$ 이상 더 높게 나타났다. case T6의 결과를 살펴보면, 동남지역 대부 분에서 양의 값이 나타나는 것을 확인할 수 있으며 특 히 울산에서 형성되어 부산 지역으로 이류된 오존의 농도가 case BASE에 비해 최고 $33 \mathrm{ppb}$ 높게 나타났
으며 또한 대구와 진해를 잇는 내륙으로 양의 값이 크 게 나타났다. $0900 \mathrm{LST}$ 와 $1500 \mathrm{LST}$ 의 각각의 시간에 서 case $\mathrm{T} 2$ 에 비해 case $\mathrm{T} 6$ 의 오존 농도가 높게 수치 모의 된 것이 확인 되었다.기온을 상승시킨 case $\mathrm{T} 2$ 와 case $\mathrm{T} 6$ 의 오존 농도의 수평장 결과를 보면 부산과 울산, 대구에서 오존의 농도가 동남권역의 다른 지역 에 비해 더욱 높게 나타나는 것을 확인 할 수 있었다. 수평장 분석을 통해 기온의 상승이 오존의 농도를 증 가시키는 요인이 되는 것으로 확인되었다.

기온 상승에 따른 대기질 모델링의 결과를 권역별 로 살펴보기 위해 Fig. 4 를 나타내었다. 여기에서 제시 된 값은 case $\mathrm{T} 2$ 의 부산, 울산, 대구권역의 일 최고 농 도 와 case BASE의 일 최고 농도의 차이, case $\mathrm{T} 6$ 의 (a)
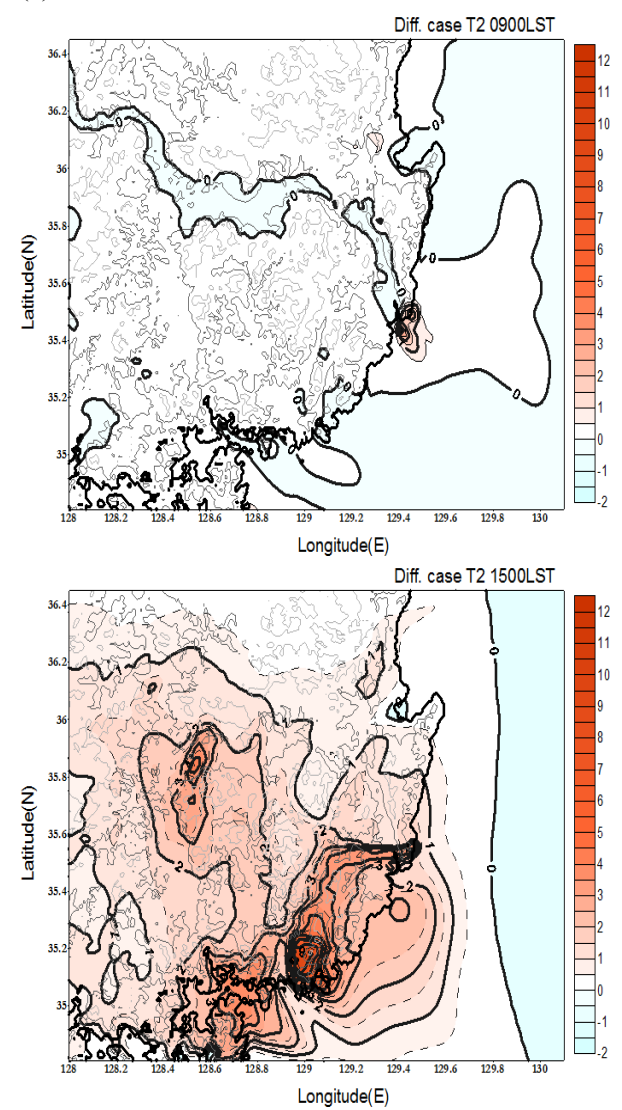

(b)
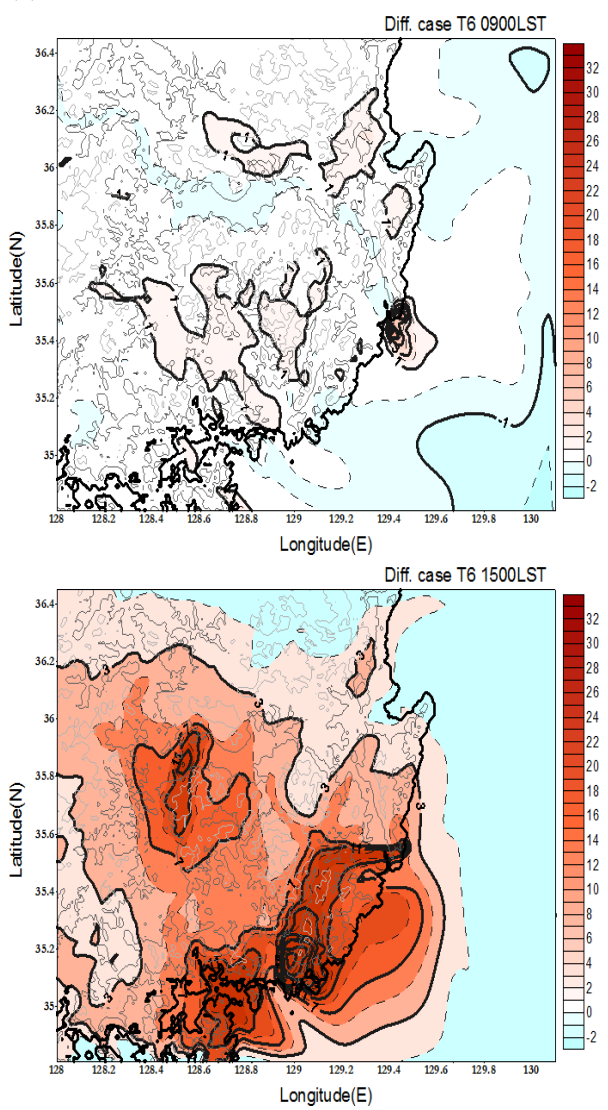

Fig. 3. Difference of simulated ozone concentration at 0900LST and 1500LST ((a): $\triangle=$ case T2 - case BASE and (b): $\triangle=$ case T6 - case BASE). 

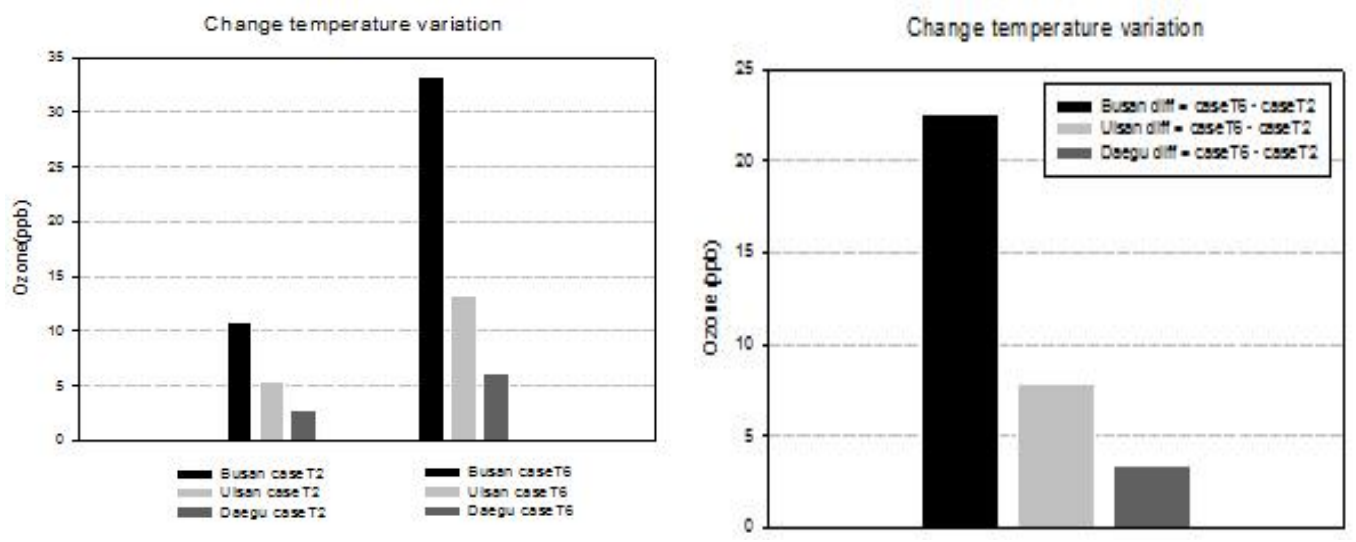

Fig. 4. The difference of ozone concentration effected by case $\mathrm{T}$ at Busan, Ulsan and Daegu.

세 도시권역의 일 최고 농도 와 case BASE의 일 최고 농도의 차이, 그리고 case T6와 case $\mathrm{T} 2$ 의 일 최고 차 이를 나타내었다. case $\mathrm{T} 2$ 의 수치모의 결과와 case $\mathrm{BASE}$ 의 결과에서 일 최고 농도의 차이는 부산, 울산, 대구에서 각각 $10.813 \mathrm{ppb}, 5.357 \mathrm{ppb}, 2.853 \mathrm{ppb}$ 증 가로 나타났다. 그리고 case T6의 수치모의 결과와 case BASE의 결과에서 일 최고 농도의 차이는 부산, 울산, 대구에서 각각 $33.313 \mathrm{ppb}, 13.292 \mathrm{ppb}, 6.218$ $\mathrm{ppb}$ 증가로 나타났다. case T6와 case T2의 차이는 부 산, 울산, 대구에서 각각 $22.5 \mathrm{ppb}, 7.936 \mathrm{ppb}, 3.365$ $\mathrm{ppb}$ 로 나타났다.

기온 상승에 의한 도시별 연직 농도의 차이를 분석 하기 위해 case BASE와 case T2, case T6의 수치모의 결과를 부산과 울산, 대구 3 개 도시에서 $1500 \mathrm{LST}$ 의 농도 profile로 나타내었다(Fig. 5). 부산의 연직 농도 를 살펴보면 case BASE의 경우 지표에서 $138 \mathrm{ppb}$ 정 도의 오존이 상층으로 올라갈수록 점차 증가하여 6 층 에서는 $150 \mathrm{ppb}$ 로 나타난다. case T2의 경우 지표에 서 $142 \mathrm{ppb}$ 의 농도가 상층으로 갈수록 증가하여 6 층 에서 $154 \mathrm{ppb}$ 으로 나타났다. 그리고 case T6에서는 지표에서 $160 \mathrm{ppb}$ 의 오존이 증가하여 6 층에서는 177 $\mathrm{ppb}$ 로 최고 농도가 나타났다. 7 층에서 모든 수치모의 결과의 연직 농도 값이 점차 감소하고 8 층에서는 3 개의 수치모의 농도 결과에서 차이가 거의 나지 않는 것을 확인 할 수 있다. 지표 농도의 수평장의 결과와 유사하게 기온 상승에 의해 연직 오존 농도 또한 상승
하는 결과가 나타났다. 그리고 울산의 연직 농도를 살 펴보면 case BASE의 경우 지표에서 $120 \mathrm{ppb}$ 의 오존 이 상층으로 갈수록 점차 증가하다 5 층에서는 127 $\mathrm{ppb}$ 로 최고 농도값을 나타낸다. case T2의 경우 지표 에서 $123 \mathrm{ppb}$ 의 농도가 상층으로 갈수록 증가하여 5 층에서 최고 농도 $130 \mathrm{ppb}$ 가 나타났다. case T6에서 는 지표에서 $130 \mathrm{ppb}$ 의 오존이 증가하여 5 층에서는 $140 \mathrm{ppb}$ 로 최고 농도가 나타났다. 6 층에서부터 모든 농도 값이 점차 감소하고 8 층에서는 3 개의 수치모의 농도가 거의 일치하였다. 울산 지역에서도 기온 상승 에 의해 연직 오존 농도 또한 상승하는 결과가 나타났 다. 대구의 경우 case BASE의 결과 지표에서 나타난 $64 \mathrm{ppb}$ 의 오존 농도가 상층까지 거의 일정하게 나타 나다가 9 층에서 감소하였다. case T2와 case T6의 오 존 농도 profile은 지표에서부터 8 층에 이르기 까지 각 실험의 지표 농도 $66 \mathrm{ppb}, 71 \mathrm{ppb}$ 가 상층까지 거의 동일하게 나타났는데 내륙에 위치한 대구의 경우 1500 $\mathrm{LST}$ 의 대기 경계층이 약 $1.5 \mathrm{~km}$ 높이로 형성되었기 때문에 연직 대기 운동이 활발해서 하층과 상층의 농 도 차이가 거의 발생하지 않는 것으로 사료되었다.

이러한 결과로 기온상승에 따른 오존 농도의 증가는 국지적으로 수평과 연직의 분포 특징이 다른 것으로 확 인되었다. 지형적 특징에 의해 대기경계층이 높은 대구 의 경우 연안지역보다 높은 고도까지 오존 농도의 증가 가 나타나 기온 상승에 따른 오존 농도의 증가는 대기 경계층 높이에 제한을 받는 것으로 사료되었다. 

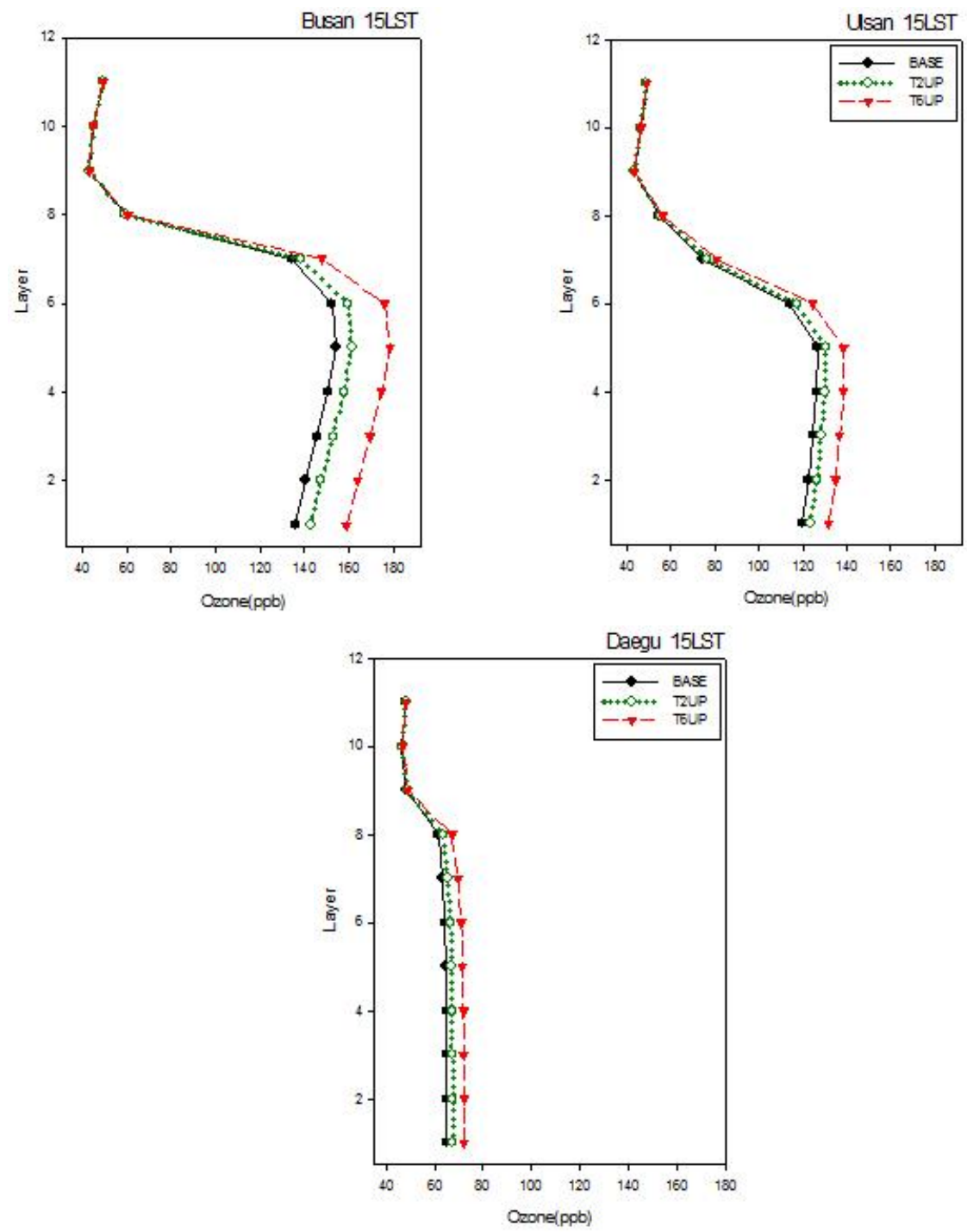

Fig. 5. Vertical profile of simulated ozone concentration.

\section{2. 풍속 변화에 따른 오존 농도}

풍속을 증가한 대기질 모델링의 결과를 권역별로 살펴보기 위해 Fig. 6을 나타내었다. 여기에서 제시된 값은 case WS $10 \%$ 의 부산, 울산, 대구권역의 1500 $\mathrm{LST}$ 농도와 case $\mathrm{BASE}$ 의 $1500 \mathrm{LST}$ 농도의 차이, case WS $20 \%$ 의 3 도시권역의 $1500 \mathrm{LST}$ 농도와 case $\mathrm{BASE}$ 의 $1500 \mathrm{LST}$ 농도의 차이, 그리고 case WS $20 \%$ 와 case $10 \%$ 의 $1500 \mathrm{LST}$ 농도의 차이를 나타내었다. case WS $10 \%$ 의 수치모의 결과와 case BASE의 1500 LST 농도의 차이는 부산, 울산, 대구에서 각각 $-28.557 \mathrm{ppb},-13.799 \mathrm{ppb},-2.677 \mathrm{ppb}$ 로 나타났다. 그 리고 case WS $20 \%$ 의 수치모의 결과와 case BASE의 결과에서 $1500 \mathrm{LST}$ 농도의 차이는 부산, 울산, 대구 에서 각각 -32.443 ppb, -17.511 ppb, -5.213 ppb로 나 타났다. case WS10\%와 case WS $20 \%$ 의 차이는 부산, 울산, 대구에서 각각 $-3.885 \mathrm{ppb},-3.711 \mathrm{ppb},-2.535$ 

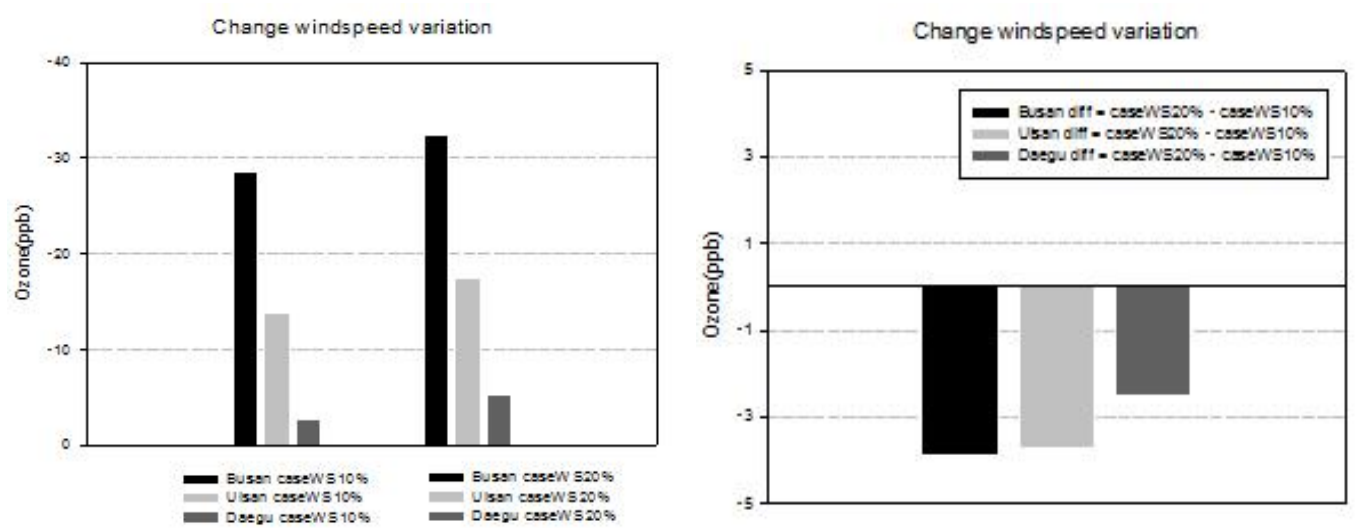

Fig. 6. The difference of ozone concentration effected by case WS at Busan, Ulsan and Daegu.

$\mathrm{ppb}$ 로 나타났다.

풍속의 증가에 따른 오존 농도의 변화를 살펴보기 위해 부산과 울산, 대구의 위도에서 단면으로 잘라 기 상장의 수렴과 발산항, 그리고 농도 분포를 분석하였 다. 부산, 울산, 대구의 수렴과 발산항을 Fig. 7에서 살 펴보면, 부산 상층으로 약하게 발산이 나타나고 있다. 같은 시간대 울산의 상층으로는 명확한 수렴과 발산 의 형태가 나타나지 않는 것을 확인할 수 있다. 또한 대구에서는 울산의 상층과 같이 명확한 수렴과 발산 의 형태가 나타나지 않는 것을 확인할 수 있다. Fig. 8 은 case BASE, case $\mathrm{WS} 10 \%$, case $\mathrm{WS} 20 \%$ 의 $1500 \mathrm{LST}$ 농도를 부산, 울산, 대구에서 중심위도를 중 심으로 단면을 잘라 분석한 결과이다. 부산의 경우 풍 속의 증가는 발산을 더욱 가중시켜 case BASE의 농 도보다 case $\mathrm{WS} 10 \%$ 의 농도가 내륙으로 침투하여 나 타났으며, case WS $20 \%$ 은 case WS $10 \%$ 의 결과보다 더욱 내륙으로 침투한 결과가 나타난다. 풍속의 증가 로 인해 발산이 강해지고 오존이 빠르게 내륙으로 쓸 려 들어가고 있으며 최고 농도도 풍속이 증가하면서 낮아지는 것을 확인 할 수 있다. 울산의 경우 case $\mathrm{BASE}$ 의 농도보다 case WS $10 \%$ 와 case WS $20 \%$ 의 결 과에서 농도가 점차 낮아지는 결과가 나타난다. 최고 농도가 $130 \mathrm{ppb}$ 에서 풍속을 $10 \%$ 증가시킨 경우에는 $120 \mathrm{ppb}$, 풍속을 $20 \%$ 증가시킨 경우에는 $110 \mathrm{ppb}$ 로 감소하였다. 울산의 상층에서 풍속의 증가는 나타났 으나 뚜렷한 발산이나 수렴이 나타나지 않아서 내륙 으로의 진입이 더디게 나타나는 것을 확인할 수 있었
다. 또한 $600 \mathrm{~m}$ 높이의 산에 가로막혀 오존의 이동 속 도가 상대적으로 느렸던 것으로 사료된다. 대구에서는 case BASE, case WS $10 \%$, case WS20\%의 1500LST 농도를 대구의 단면으로 잘라 나타낸 것이다. case $\mathrm{BASE}$ 의 농도보다 case $\mathrm{WS} 10 \%$ 와 case WS $20 \%$ 의 결 과에서 농도가 점차 낮아지는 결과가 나타난다. 최고 농도가 $95 \mathrm{ppb}$ 에서 풍속을 $10 \%$ 증가시킨 경우에는 $90 \mathrm{ppb}$, 풍속을 $20 \%$ 증가시킨 경우에는 $85 \mathrm{ppb}$ 로 감 소하였다. 풍속이 증가하면서 수렴이 더 강해져 오존 은 거의 이류 되지 않는 상태로 나타난다.

\section{4. 결 론}

본 연구에서는 대규모 오염물질의 배출원이 위치 하며 산악과 분지, 연안의 특징적 지형으로 인한 복잡 한 국지순환이 발생하는 동남지역을 대상으로 기후변 화에 의한 기상요인의 변화와 오존 농도의 변동을 분 석하기 위해 수치모의를 수행하였다. 중규모 기상모 델인 WRF를 통해 기상장 수치모의를 실시하였으며, 대기질 수치모의는 $\mathrm{CMAQ}$ 으로 수행하였다.

동남 지역의 부산과 울산, 대구를 중심으로 각 기상 요인(기온, 풍속)을 대기질 수치모의에 적용하였다. 기온의 변화에 따른 오존 농도 분석을 위해 기온을 $2{ }^{\circ} \mathrm{C}, 6^{\circ} \mathrm{C}$ 상승시킨 case $\mathrm{T} 2$ 와 case $\mathrm{T} 6$ 의 수치실험을 실시하였다. 풍속 변화에 따른 오존 농도의 분석을 위 해 풍속을 $10 \%, 20 \%$ 상승시킨 case $\mathrm{WS} 10 \%$ 와 case $\mathrm{WS} 20 \%$ 의 수치실험을 실시하였다. 

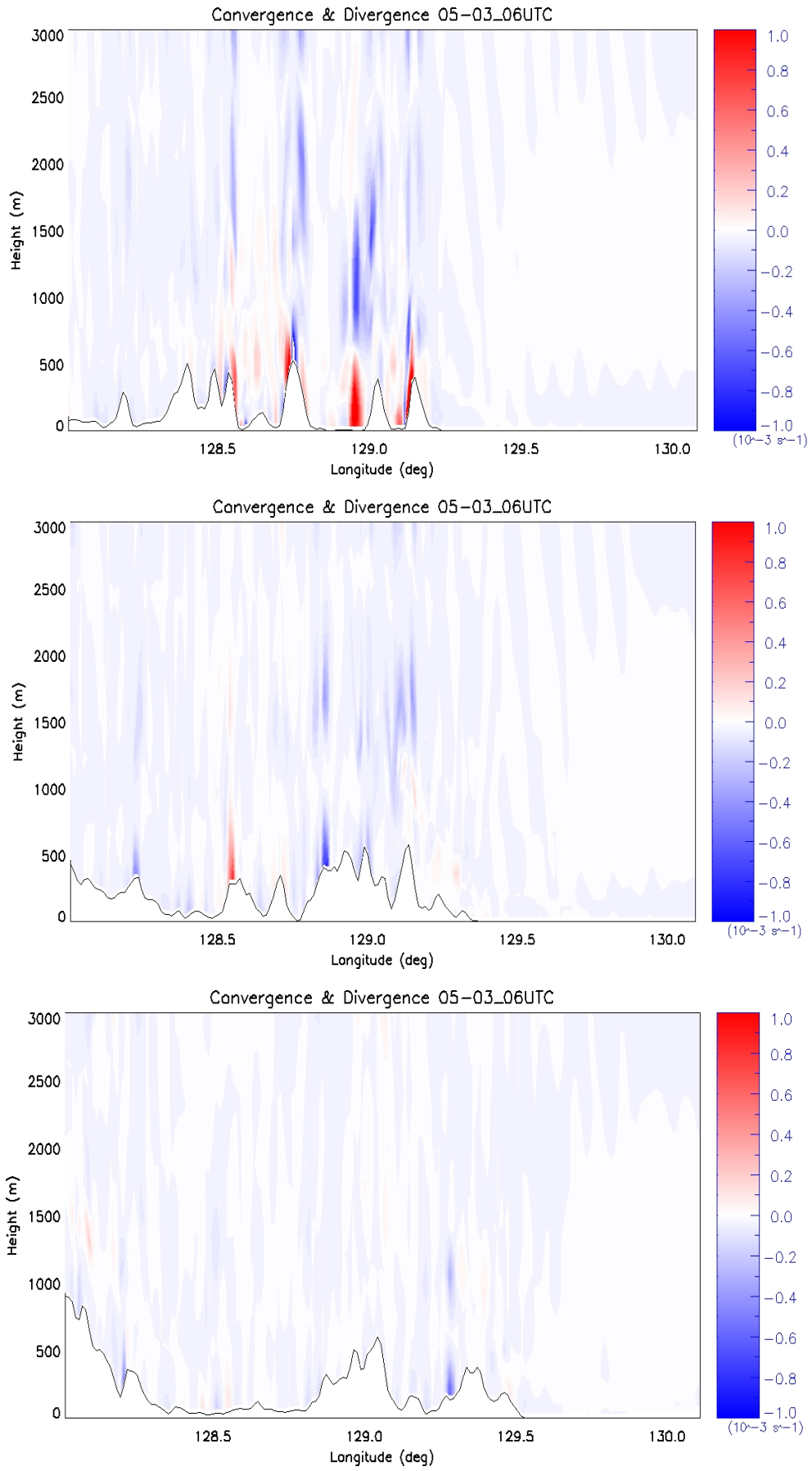

Fig. 7. Vertical distributions of the simulated convergence \& divergence for Busan, Ulsan, Daegu cross section at 1500LST. 

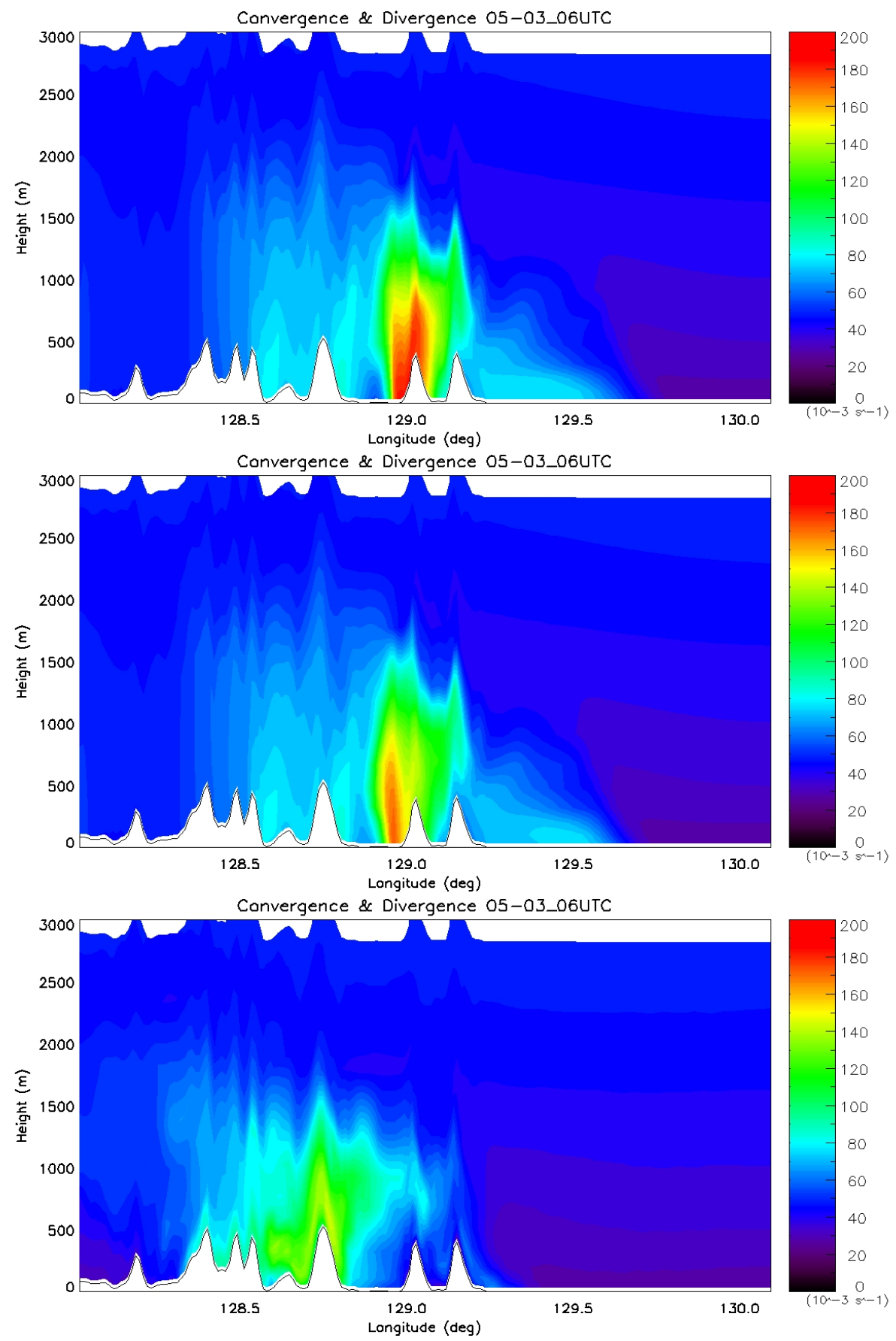

Fig. 8(a). Vertical distributions of the simulated ozone concentration for Busan cross section at 1500LST. 

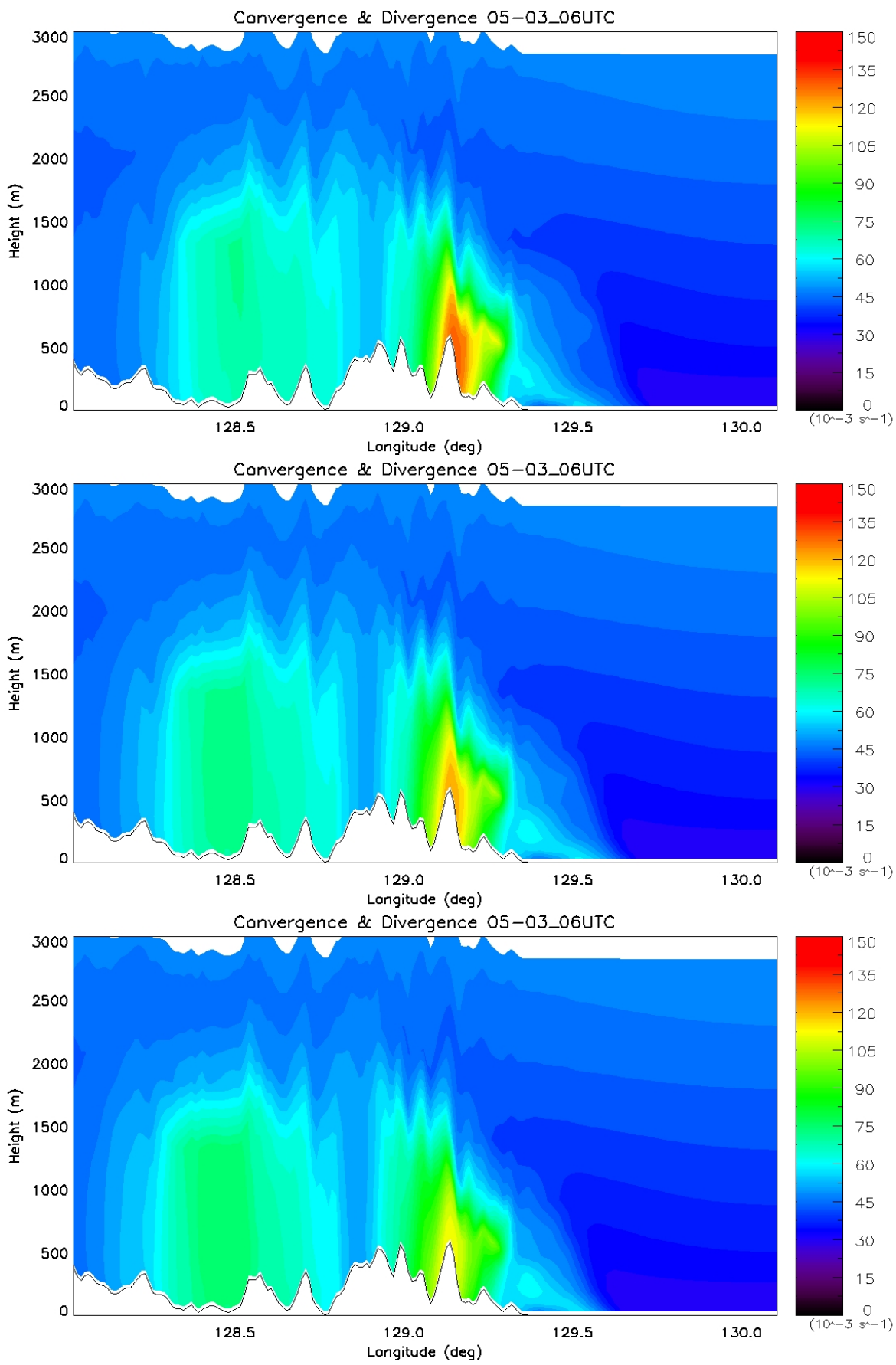

Fig. 8(b). Vertical distributions of the simulated ozone concentration for Ulsan cross section at 1500LST. 

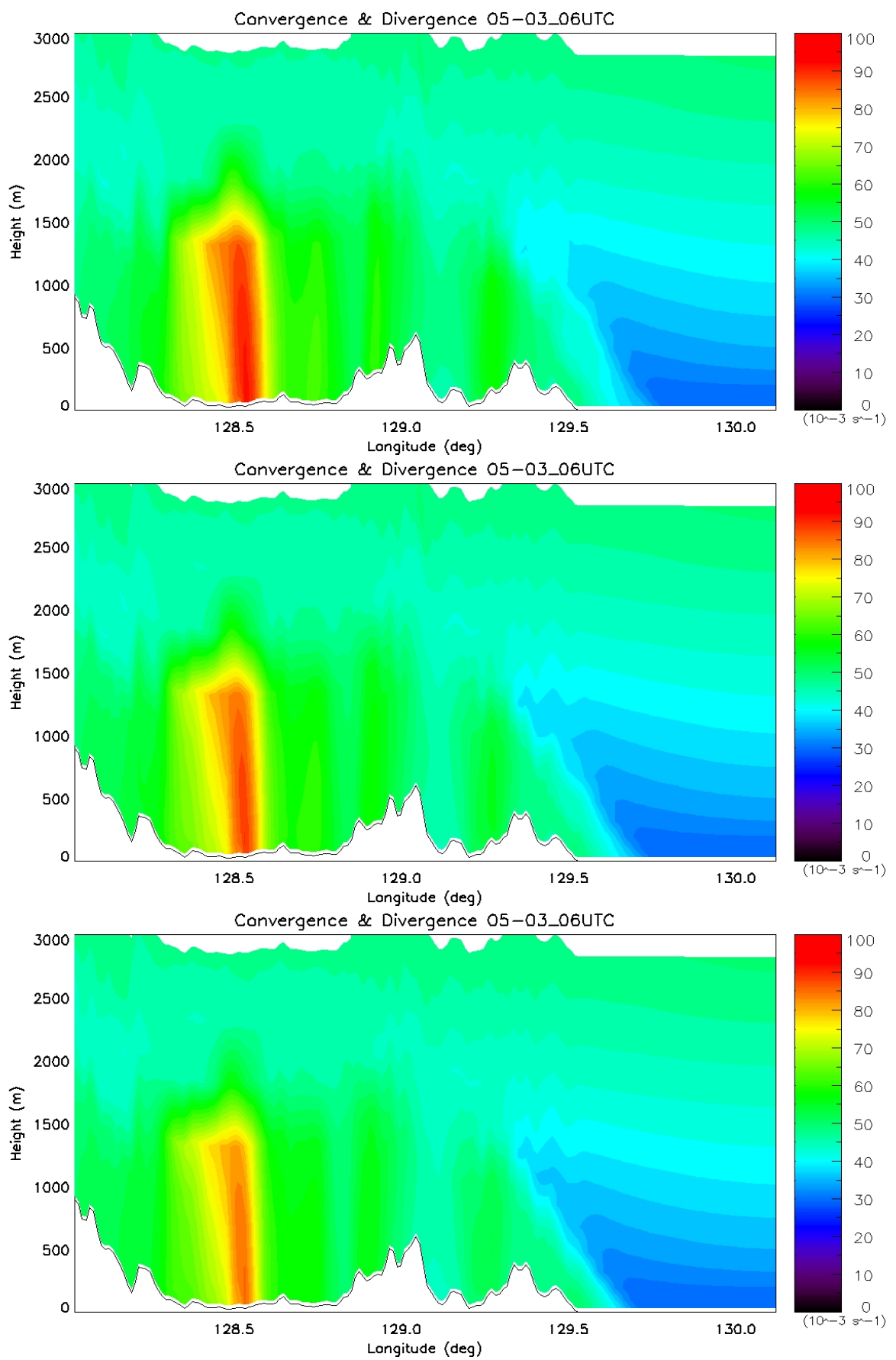

Fig. 8(c). Vertical distributions of the simulated ozone concentration for Daegu cross section at 1500LST. 
수치모의 결과를 통해 기온의 상승에 따라 부산과 울산, 대구의 오존 농도는 증가하는 결과를 보였고, 부 산 지역에서 가장 많은 오존 농도의 증가가 나타났으 며 기온이 $6^{\circ} \mathrm{C}$ 상승 했을 경우 최고 $33.3 \mathrm{ppb}$ 이상 오 존의 농도가 증가되었다. 다음으로 울산 $\left(6^{\circ} \mathrm{C}, 13.3\right.$ $\mathrm{ppb})$, 대구 $\left(6^{\circ} \mathrm{C}, 6.2 \mathrm{ppb}\right)$ 의 순으로 오존 농도의 증가 를 보였다. 기온을 $2^{\circ} \mathrm{C}$ 상승시킨 결과에서는 부산에서 $10.8 \mathrm{ppb}$, 울산에서 $5.3 \mathrm{ppb}$ 대구에서 $2.9 \mathrm{ppb}$ 의 증가 가 나타났다. 이러한 결과는 지형적 특징으로 인해 내 륙지역인 대구에서 연안지역인 부산과 울산 보다 높 은 고도까지 오존 농도의 증가가 나타나기 때문이다. 풍속의 증가에 따라 동남 지역의 도시에서는 오존 농 도의 감소가 나타났다. $1500 \mathrm{LST}$ 의 기준으로 풍속을 $20 \%$ 증가시켰을 때, 수치모의 결과에서 부산의 경우 오존 농도 $32.4 \mathrm{ppb}$ 의 감소가 나타났으며, 울산의 경 우 $17.5 \mathrm{ppb}$, 대구의 경우 $5.2 \mathrm{ppb}$ 의 감소가 나타났다. 풍속을 $10 \%$ 증가시킨 결과 부산에서 $28.5 \mathrm{ppb}$, 울산 에서 $13.7 \mathrm{ppb}$ 대구에서 $2.6 \mathrm{ppb}$ 의 감소가 나타났다.

이는 풍속의 증가로 지형적 발산장이 강화 혹은 약 화 되어 오존 농도의 감소와 이류를 초래하기 때문으 로 판단된다. 수치모의 결과를 통해 도시별 특징을 살 펴보면, 부산과 울산의 경우 기온과 풍속의 변화에 따 라 오존의 농도가 큰 폭으로 증가·감소하는 경향이 나타났고, 대구의 경우 기상 요인의 변화에 대한 오존 농도의 변동성이 다른 두 도시에 비해 작게 나타났다. 향후 기후 변화에 따른 기상 요인의 변동은 불가피 할 것으로 전망되는 가운데 각 도시의 기상 요인에 의한 오존 농도의 변동성 자료는 활용도가 높다고 전망되 며, 이에 따른 오존에 관한 저감 대책은 도시별 기상요 인의 변동성을 고려해야 할 것으로 사료된다.

\section{감사의 글}

이 논문은 부산대학교 자유과제 학술연구비(2년) 의 지원을 받아 연구되었음을 감사드립니다.

\section{참 고 문 헌}

전원배, 이화운, 이순환, 최현정, 임헌호, 2009 , 상세 해수 면 기온자료의 반영에 따른 국지 기상장 개선에 관 한 수치연구, 한국대기환경학회지, 25, 304-315.

Carvalhoa, A., Monteiroa, A., Ribeiroa, I., Tchepela, O., Mirandaa, A. I., Borregoa, C., Saavedrab, S., Soutob, J. A., Casaresb, J. J., 2010, High ozone levels in the northeast of Portugal: Analysis and characterization, Atmospheric Environment, 44(8), 1020-1031.

Camalier, L., Cox, W., Dolwick, P., 2007, The effects of meteorology on ozone in urban areas and their use in assessing ozone trends, Atmospheric Environment, 41(33), 7127-7137.

Fujibe, F., Detection of urban warming in recent temperature trends in Japan, 2009, INTERNATIONAL JOURNAL OF CLIMATOLOGY, 29(12), 1811-1822.

Gabriel, A. V., Brian, J. S., 2007, Increased tropical Atlantic wind shear in model projections of global warming, GEOPHYSICAL RESEARCH LETTERS, 34, L08702, doi:10.1029/2006GL028905.

Jianhui, B., Gengchen, W., Mingxing, W., 2005, An empirical correlation between surface $\mathrm{O} 3$ and its factors, Atmospheric Environment, 39(25), 4419-4423.

John, P. D., Peter, J. A., Spyros, N. P., 2007, Sensitivity of ozone to summertime climate in the eastern USA: A modeling case study, Atmospheric Environment, 41(7), 1494-511.

Lee, H. W., Choi, H. J., Lee, S. H., Kim, Y. K., Jung, W. S., 2008, The impact of topography and urban building parameterization on the photochemical ozone concentration of Seoul, Korea, Atmospheric Environment, 42(18), 4232-4246. 